\title{
Approaches for Obtaining Audit Evidence at Fair Value Measurement
}

\author{
N.A. Prodanova ${ }^{1}$, L.B. Trofimova ${ }^{2}$, O.E. Bashina ${ }^{3}$, \\ O. E. Kachkova ${ }^{4}$, N.D. Ilienkova ${ }^{5}$, T.A. Polyanskaya ${ }^{6}$
}

\begin{abstract}
:
Purpose: The article provides a comparative analysis of several fair value measurement techniques contained in IFRS and US GAAP standards in order to select the valuation method of financial reporting elements that is most applicable to auditing.

Design/Methodology/Approach: A study of the conceptual issues of valuation of accounting objects at fair value in order to select a valuation technique that allows to evaluate the asset or liability with maximum accuracy.

Findings: The authors have developed a methodology for auditors to select the most accurate estimates, considering prices prevailing only in observed markets.

Practical Implications: The application of the developed methodology for determining fair value can be used by auditors to form a reliable professional judgment in obtaining audit evidence.

Originality/Value: The authors proposed a new audit algorithm for the validity of the valuation of assets and liabilities at fair value, based on obtaining audit evidence to determine whether the estimates in the financial statements are reasonable in relation to the applicable financial reporting framework or if they are distorted.
\end{abstract}

Keywords: Assessment, fair value, audit, methodology, evidence, IFRS, estimated values.

JEL codes: M40, F15, F20.

Article Type: Research study.

\footnotetext{
${ }^{1}$ Plekhanov Russian University of Economics Stremyanny lane, 36, Moscow, 117997, Russia, prodanova-00@mail.ru

${ }^{2}$ Plekhanov Russian University of Economics Stremyanny lane, 36, Moscow, 117997, Russia

${ }^{3}$ Moscow University for the Humanities, YunostiSt., Moscow, 111395, Russia

${ }^{4}$ Financial University under the Government of the Russian Federation, Leningradsky

Prospect, 49, Moscow, 125993, Russia

5"Faiya Star», Pokrovsky Boulevard, 14/6, Moscow, 109028, Russia

${ }^{6}$ Main control Department of Moscow, Novy Arbat str., 36, Moscow, 121099, Russia
} 


\section{Introduction}

In international and Russian accounting practices, issues related to the valuation of elements of financial statements are becoming increasingly important, with fair value being the most applicable and most discussed in the valuation of assets and liabilities. International Committee on valuation standards (International Valuation Standards Committee - IVSC) develops International Standards for evaluation. IVSC unites professional organizations of appraisers from many countries, including the Russian society of appraisers.

In March 2014, the IASB and IVSC issued joint protocols on cooperation in establishing fair value measurement standards and guidelines for the preparation of International Financial Statements in order to resolve significant differences in the methodology for their determination. In April 2016, the IVSC has released a new draft of the international valuation standards and their conceptual bases in 2017. The bill provides for mandatory use of the definition of "fair value" as formulated in the standards of the International Accounting Standards Board (IASB) and the Committee on financial accounting standards of the United States (FASB), as it described the circumstances under which the selection of one valuation method or combination thereof for each of the three methods (market, income and cost).

Russia is also developing conceptual issues of transition in the assessment of objects of accounting at fair value. Thus, in November 2018, the Ministry of Finance of the Russian Federation published and recommended to apply the document "Conceptual framework for financial reporting" (hereinafter - the Concept) ${ }^{7}$ adopted by the IFRS Council, which presents the following classification of types of assessment of financial reporting elements (Figure 1).

\section{Literature review}

Fair value is the subject of a separate international standard IFRS 13, which contains its definition, sets out the basis for its assessment, as well as discloses information about the estimates. IFRS 13 describes a complex methodology for its definition, which is reflected in the work of economists. Thus, A.I. Artemenkov (Artemenkov, A.I. 2017) described in detail the theory of fair value measurement in professional valuation. Economist T.Yu. Druzhilovskaya (Druzhilovskaya, 2018) revealed the main problems of practical application of fair value, and scientists L.V. Prishchepa (Prishchepa, 2017) and L.B. Trofimova (Trofimova, 2012) considered the essence of fair value in the system of market valuation of accounting objects.

Conceptual framework for the presentation of financial statements https://www.minfin.ru/ru/perfomance/accounting/mej_standart_fo/docs/\# date of application 24.05.2019. 
Figure 1. Classification of the assessment of financial reporting elements

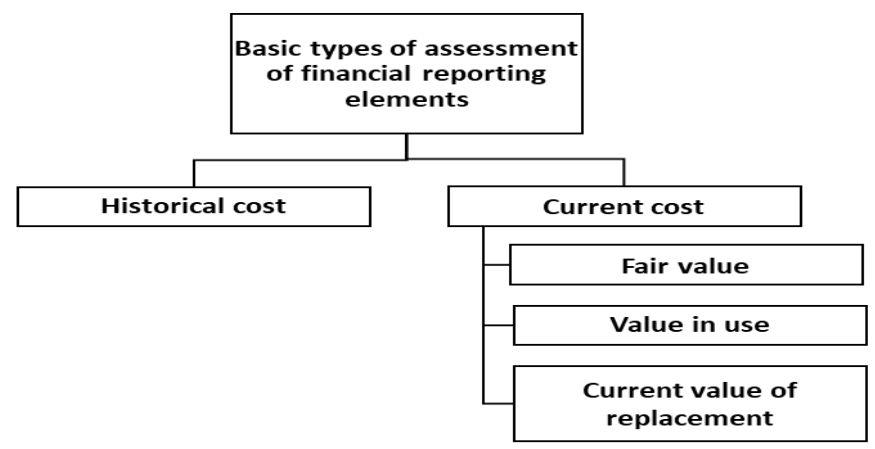

Source: Compiled by the authors on the basis of Concepts.

A.R. Shidov (Shidov, 2018) conducted an analysis of discrepancies in the assessment of fair value according to IFRS and RAS. A.V. Kozlova (Kozlova et al., 2017) devoted their works to the problematic issues of the Russian audit) and D.V. Kuznetsova (Kuznetsova et al., 2017). However, attention has not been paid by economists to the study of the audit features in relation to the validity of the assessment of elements of financial statements at fair value (Yücel et al., 2010; Adamczyk et al., 2019; Arribas et al., 2019; Labanauskis et al., 2019; Goryushkina et al., 2018; Leonteva et al., 2018; Ponomareva et al., 2019; Puryaev, 2015).

\section{Methodology}

Tips SFU United States and IFRS in the newly published standards often apply the concept of fair and not historical cost. US GAAP standards, according to interpretations of generally accepted accounting principles, have several types of definitions of fair value (Bragg, 2010) (Table 1).

Table 1. Modifications to fair value definitions contained in several US GAAP standards

\begin{tabular}{|l|l|l|}
\hline $\begin{array}{l}\text { № } \\
\mathbf{p} / \mathbf{p}\end{array}$ & The concept of «fair value» & ASC Standards \\
\hline $\mathbf{1}$ & $\mathbf{2}$ & $\mathbf{3}$ \\
\hline 1. & $\begin{array}{l}\text { The purchase or sale price of the asset between } \\
\text { the parties in a normal transaction. }\end{array}$ & $\begin{array}{l}\text { ASC 815 «Accounting for derivatives } \\
\text { and hedging transactions». }\end{array}$ \\
\hline
\end{tabular}




\begin{tabular}{|c|c|c|}
\hline $\begin{array}{l}\text { № } \\
\text { p/p }\end{array}$ & The concept of «fair value» & ASC Standards \\
\hline 1 & 2 & 3 \\
\hline 2. & $\begin{array}{l}\text { The cost, which can be obtained by the usual } \\
\text { operations of purchase and sale between the } \\
\text { parties on the valuation date. Although GAAP } \\
\text { applies fair value to assets and liabilities, this } \\
\text { definition of fair value also applies to equity } \\
\text { instruments. }\end{array}$ & $\begin{array}{l}\text { ASC } 820 \text { «fair value Measurement and } \\
\text { disclosure». }\end{array}$ \\
\hline 3. & $\begin{array}{l}\text { The value that can be obtained in the ordinary } \\
\text { course of a sale transaction between the parties } \\
\text { at the valuation date. }\end{array}$ & $\begin{array}{l}\text { ASC } 825 \text { « Financial } \\
\text { Tools». }\end{array}$ \\
\hline 4. & $\begin{array}{l}\text { Amount of cash or cash equivalents of the } \\
\text { value of consideration received or receivable in } \\
\text { a transaction between buyer and seller in } \\
\text { respect of a current sale of real estate (other } \\
\text { than a forced or liquidated sale). }\end{array}$ & ASC 970 « real Estate ». \\
\hline
\end{tabular}

Source: Translation of the author's interpretation and application of generally accepted accounting principles S. Bragg (Bragg, 2010).

In accordance with ASC 820, the following approaches are used to determine fair value:

1) market;

2) profit;

3) cost.

The IASB has several definitions of fair value in several standards (Figure 2). The definition contained in the new IFRS 13 standard has a more universal application, although in our view it should have been emphasized that the transaction must be concluded between independent parties. IFRS 13 introduces a fair value hierarchy within which sets the priority of the original data when measuring the fair value (Trofimova, 2015) (Figure 3).

The first level includes quotes in the active market for identical assets or liabilities, information about which the company can obtain at the valuation date (Pujiyono et al., 2019; Maguth and Koskey, 2019; Cherepovitsyn et al., 2016; Romasheva et al., 2018; Smirnova and Izotov, 2017). The second level includes inputs other than the quotes included in the first level observed for the asset or liability directly or indirectly. The third level includes unobservable inputs to the valuation of an asset or liability. 
Figure 2. Comparative analysis of the definitions of fair value contained in IFRS

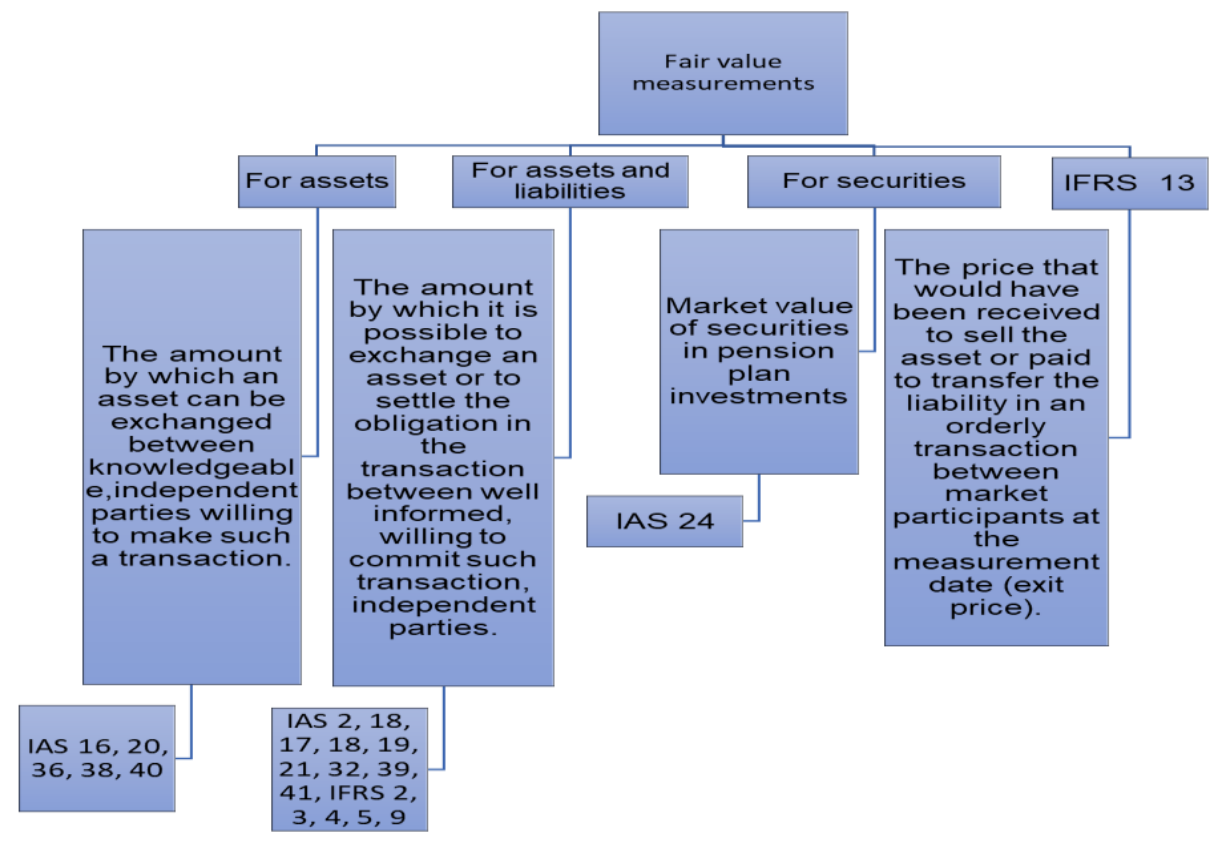

Figure 3. Hierarchical structure of fair value measurement (Weinstein et al., 2013).

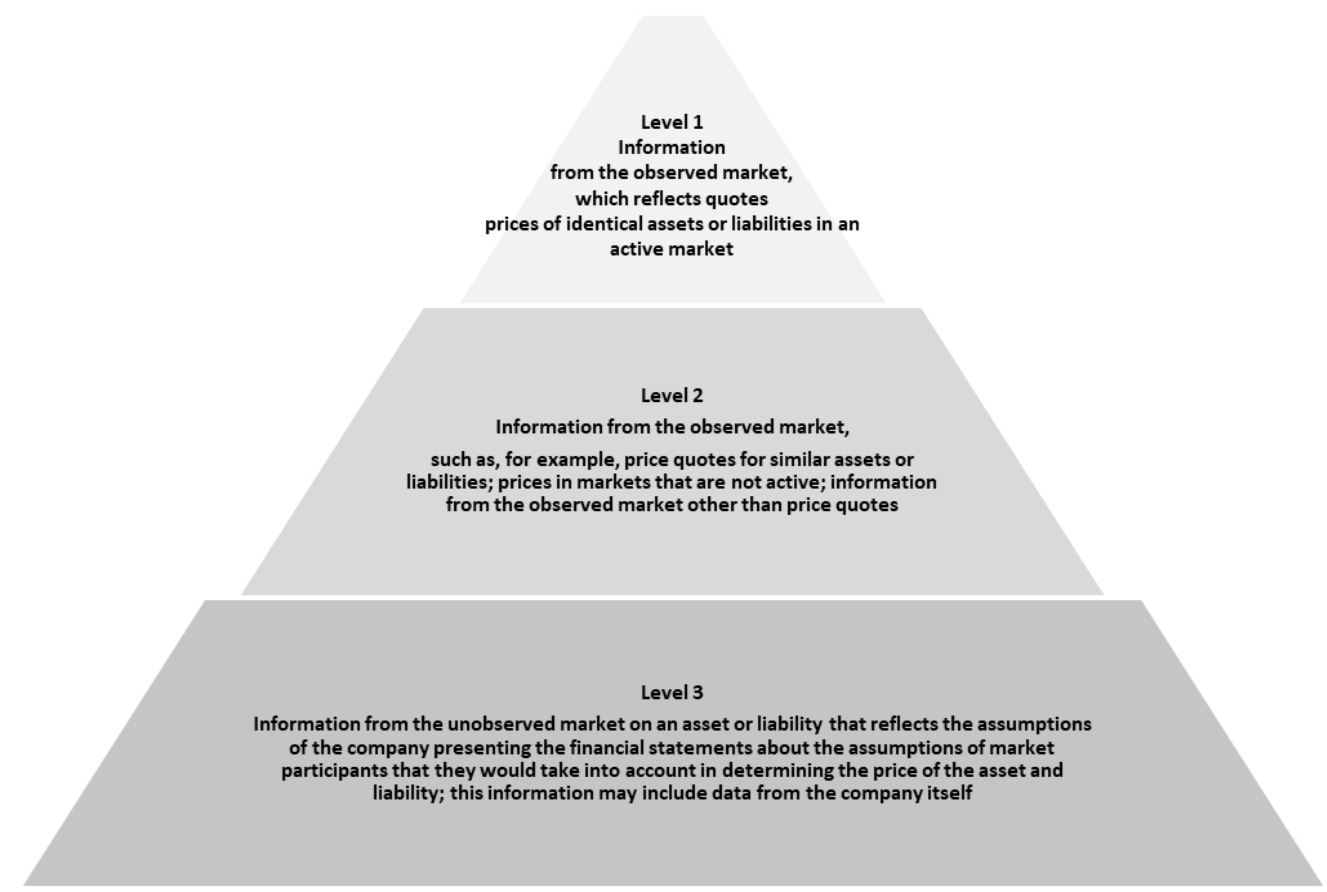


Fair value measurement assumes that transactions take place in an active (main) market, i.e. the market with the largest volume and level of activity for an asset or liability. The best indicator of fair value is a quotation in an active market, that is, a market in which transactions with an asset or liability are made with enough frequency and volume to ensure that price information is provided on an ongoing basis (Korableva et al., 2018). Fair value, according to IFRS 13, is the price paid or an obligation transferred between willing parties to a transaction at a certain date, and this price must be measurable. However, it can be argued that measurement, disclosure and verification of information is a complex process, as the formation of an assessment is usually developed by management (or the evaluators employed by the audited company) using significant professional judgment (Korableva et al., 2019). Moreover, the existence of special specific conditions, such as the absence of an active market, whose prices could be used as a basis, and the availability of information from other sources also complicates the audit process (Dobrovolskiene et al., 2017; Singareddy et al., 2019; Aleksandrova et al, 2017; Gurman et al., 2017; Yemelyanov et al., 2018; 2019).

Fair value as a measurement method in the financial statements is most commonly used in reports prepared under IFRS. However, due to the existence of several types of assessments and the approaches taken by the professionals involved in the asset assessment, the quality of the assessment may vary.

\section{Results}

Both in assessing and verifying the correctness and completeness of the disclosure of the assumptions underlying the determination of fair value, professional judgment is of paramount importance. The high degree of subjectivity inherent in professional judgment concerns investors, auditors and regulators alike. The European securities and markets (European Securities and Markets Authority, ESMA) regularly publishes extracts from its decisions, which can be interpreted as the official position of the regulators and a guide to action. ESMA considered the completeness of disclosure of non-observable data at the third level of the fair value hierarchy of a number of private companies. At the same time, attention was drawn to the fact that the professional judgments of companies in determining the fair value did not coincide with the opinion of the regulator. At the same time, the fair value audit is regulated by the international auditing standard.

The order of the Ministry of Finance of the Russian Federation of January 9, $2019 \mathrm{~N}$ 2n put into effect the international standard of audit (International Standard on Auditing - ISA) 540 "Audit of estimated values, including the assessment of fair value, and the corresponding disclosure of information", combining and replacing two previously existing standards ISA (ISA) 545 "Audit of measurement and disclosure of fair value" and ISA (ISA) 540 "Audit of estimated values" of 2016. 
The new ISA 540 establishes the auditor's responsibilities for the audit of estimates, including fair value measurements. In accordance with this standard, some items of the financial statements cannot be accurately estimated, they can only be estimated, such items are referred to as "estimates".

The concept of financial reporting may include the measurement of fair value based on a hypothetical contingent current transaction that takes place on market conditions between "market participants". In this assessment, it is important to answer the following questions:

1. What is the way to identify transactions that require recognition of estimated values in the reporting;

2. - What is the method of calculating the estimated values;

3. - What the estimated values are based on;

4. - What is the method used to calculate the estimated value;

5. - What controls are in place;

6. - Attracted the leadership expert;

7. - Are there any assumptions when calculating estimates;

8. - Whether there is an assessment of the impact of uncertainty in the assessment.

The auditor is required to determine, on the basis of the audit evidence, whether the estimates in the financial statements are reasonable in relation to the applicable financial reporting concept or whether they are misstated. Estimates calculated using data from open sources, such as published interest rates or stock quotes. For fair value measurement, such data can be called "observable". Non-observable valuation data include the following types of fair value measurements:

9. - valuation of derivative financial instruments that are not traded on the stock exchange;

10. - estimates based on a model developed by the organization itself;

11. - assumptions or non-market observable inputs.

Not all financial statements that require fair value measurement are characterized by measurement uncertainty. For example, this may be the case where there is an active and open market for individual financial statements that provides publicly available and reliable information on the prices at which actual transactions are conducted. In such cases, published quotations are usually the best audit evidence of fair value. However, estimation uncertainty may exist even if the method of estimation and the data are very well defined.

For example, it may be necessary to adjust the valuation of securities quoted on the active and open market at the declared market value if the package of such securities is significant in terms of market size or the liquidity of such securities is limited. In 
addition, the uncertainty of the valuation may be affected by General economic factors existing at the time of its calculation, such as the lack of liquidity in a particular market.

Fair value measurements can be calculated using both observable and unobservable inputs. If fair value estimates are calculated using unobservable inputs, the auditor may examine, for example, how management confirms the following:

12. how to determine the characteristics of market participants important for the calculation of the estimated values;

13. - what are the changes that management has made to its assumptions in order to express its opinion on the assumptions used by market participants;

14. take into account whether the user the best information that was available at his disposal under the circumstances;

15. - where applicable, how comparable transactions, assets and liabilities are accounted for in management's assumptions.

In accordance with the international standard ISA 540, the calculation of a point estimate or range of estimates can be a reliable response to risks in cases where the estimated value is calculated in a way different from the standard data processing in the accounting system of the organization.

Auditors apply a method of narrowing the range of estimates to a level where all the results of the range are considered reasonable, in particular by excluding from the range of estimates the results at its extreme points, which, in the opinion of the auditor, are unlikely.

\section{Discussion}

Indonesian scientists Mita, A.F. and Siregar, S.V. (Mita and Siregar, 2019) proved in their scientific work, examining 54 companies registered on the Indonesian stock exchange in terms of the appropriateness of choosing a fair value in the evaluation of investment property.

Californians Lu, H.Y. and Wang, S. (Lu and Wang, 2019) justified the importance of choosing a relevant assessment of income and expenses, pointing out that the correct method of determining the fair value directly affects the quality of the audit.

In their research, Pannese Danny and Alan Del Favero (Pannese and Favero, 2010) cite the following list of problems faced by auditors in conducting a fair value review:

- the price assigned to an asset or liability may not reflect its economic reality;

- there may be deviations in the fair value of an asset or liability above the materiality level; 
- the third level of the fair value hierarchy is based on unobserved markets, so it is difficult to verify the market price;

- there is often a real opportunity for managers to manipulate revenues in the absence of a quality fair value measurement test.

Many economists paid attention to the problems of valuation of assets and liabilities at fair value in a market economy, in particular the economist S.L. Lozhkina (Lozhkina, 2018) studied the features of the formation of the reliability of prices depending on the different degree of market activity (Nikolaeva et al., 2018; Talovina et al., 2017; Smirnova and Rudenko, 2016; 2017).

Formation evaluation measurement of fair value is inherently very subjective process, so as specialists who installs it, can use a variety of professional judgement, as previously mentioned. There are also a number of variables and possible assumptions, each of which can be used as an estimate, and this, in turn, causes difficulties in the audit, compared with other types of estimates.

The procedure for calculating the fair value is quite complex, labor-intensive and requires high qualification of specialists. In this regard, many companies invite an independent appraiser, which can significantly reduce the time of preparation of reports and improve its reliability and independence from subjective assessments of management in the eyes of auditors and regulators.

\section{Conclusion}

Based on the audit evidence obtained, the auditor may conclude that there is a difference between the estimated value and the management's point estimate. If the audit evidence supports a point estimate, the difference between the auditor's point estimate and the management's point estimate is a misstatement. If the auditor finds that the audit evaluation of the range provides sufficient and appropriate audit evidence, such evidence will not support management's point assessment that is outside the audit evaluation of the range. In such cases, the amount of distortion will be no less than the difference between management's point estimate and the nearest point in the range's audit estimate. When auditing fair value measurements, the following things should be noted:

1) availability of audit documentation;

2) understanding the relationship between management's assumptions in the assessment and the actual values of the methodological characteristics of these measurements;

3) training of the company's clients;

4) communicate with third-party evaluators;

5) assessment of qualification of specialists;

6) review of the work carried out by the evaluators. 
Auditors need to understand and document judgments and the rationale for the guidance in measuring the fair value. Also, it is necessary to consider the requirements contained in ISA 500 "Audit evidence".

Procedures that are commonly used and documented to assess the reasonableness of the fair value applied by management of the audited company are included but are not limited to comparing management's assumptions about market research and financial documentation of similar companies. As a rule, the company's management or its third-party experts develop a model for assessing business or intangible assets. Regardless of who does it, in any case the audited company is responsible for providing the information that will be used as the source data for the audit. The input data for the model may include specific management assumptions, such as a 5\% increase in revenues over the next five years, which are classified as "unobservable", that is, this information cannot be confirmed by a person who is not familiar with the internal management reports of the company. Upon detection by the auditor of the prices prevailing in the market is unobserved, they must be removed. After initial recognition, when measuring fair value using a method or measurement methods that use unobservable resources, the reporting entity should ensure that these measurement methods reflect observable market data (such as the value of a similar asset or liability) at the measurement date.

Part of the auditors' job is not just to review the company's financial statements. In addition, they may explain to clients some aspects of the reporting of assets, liabilities, which may take the form of an expression of opinion, or disagreement related to their accounting. Auditors should "train" their customers, that is, explain to them the need to understand the relevance of the assessment of the model, approaches. This gives the audited company a clearer idea of the documentation that needs to be provided to the auditing organization and can motivate the top management of the audited entity to better understand how the fair value measurement was formed. Moreover, it is also a reminder to management that it is responsible for the financial statements, including fair value measurement, even if they have been prepared by third party professionals (Korauš et al., 2019; Dyussembekova et al., 2019; Dunets et al., 2019).

Management, evaluators and auditors should agree on what methods of fair value formation will be used well in advance of the assessment. Auditors should ask the management of the company to provide them with a preliminary valuation method, which will be used in determining the value, as they are the necessary information. The discussion should include potential issues related to the definition of the assessment (e.g. limited customer data) and any other issues that may affect the analysis. This method of communication will help to save considerable time and avoid possible delays associated with the audit, instead, and avoid uncoordinated expectations after receiving the evaluation report. 
The assessment of the qualification of evaluators includes an assessment of whether the evaluator has the necessary competence, capabilities and objectivity. The review process should include an examination of the interests and relationships that may jeopardize the objectivity of the evaluator. All considerations should be carefully documented in the auditor's file. When conducting an audit, auditors should determine whether appraisers use different methods or use a common approach to the type of evaluation and whether they can explain why they used or did not use them. Thus, the use of the above methods can help auditors to make the most reliable assessment of how accurately the fair value of the asset is determined, as well as to minimize risks.

In order to improve the audit of the fair value of assets and liabilities, further research is required in the following three areas:

1) reducing the impact of material uncertainty on the auditor's conclusion by requiring the auditor to;

2) increasing the level of professional skepticism of the auditor by changing the procedures, starting with the analysis of events after the reporting date, then carrying out an independent fair value assessment and only then ending with the analysis of the internal control over the fair value assessment process;

3) clarification of the procedure for using the results of the work of third parties (including professional appraisers).

\section{References:}

Adamczyk, M., Betlej, A., Gondek, J., Ohotina, A. 2019. Technology and sustainable development: towards the future? Entrepreneurship and Sustainability Issues, 6(4), 2003-2016. http://doi.org/10.9770/jesi.2019.6.4(32)

Aleksandrova, T., Aleksandrov, A. \& Nikolaeva, N. 2017. An investigation of the possibility of extraction of metals from heavy oil. Mineral Processing and Extractive Metallurgy Review, 38(2), 92-95. doi:10.1080/08827508.2016.1262860

Arribas, I., Espinós-Vañó, M.D., García, F., Tamosiuniene, R. 2019. Negative screening and sustainable portfolio diversification. Entrepreneurship and Sustainability Issues, 6(4), 1566-1586. https://doi.org/10.9770/jesi.2019.6.4(2)

Artemenkov, A.I. 2017. On theories of fair value estimation in professional valuation Assessment questions. Publisher: Russian Society of Appraisers (Moscow), 4(90), 40-47 (In Russian).

Bragg. S.M. 2010. GAAP 2011: Interpretation and Application of Generally Accepted Accounting Principles. John Wiley \& Sons, Inc. Canada.

Cherepovitsyn, A., Moe, A. \& Smirnova, N. 2016. Development of transboundary hydrocarbon fields: Legal and economic aspects. Indian Journal of Science and Technology, 9(46), doi:10.17485/ijst/2016/v9i46/107527.

Dobrovolskienė, N., Tvaronavičienė, M., Tamošiūnienė, R. 2017. Tackling projects on sustainability: A Lithuanian case study. Entrepreneurship and Sustainability Issues, 4(4), 477-488. http://doi.org/10.9770/jesi.2017.4.4(6)

Druzhilovskaya, T.Yu. 2018. Problems of practical application of fair value for valuation of 
accounting objects. Publisher: Publishing house Finance and Credit Publishing House (Moscow), Volume, 21, 9(447), 1086-1099 (In Russian).

Dyussembekova, G., Reshina, G., Primbetova, S., Sultanova, M. \& Beisembayeva, G. 2019. Role and importance of the damu enterprise development fund and international investment funds in implementing project and leasing financing programs in kazakhstan. Space and Culture, India, 6(5), 156-165. doi:10.20896/saci.v6i5.442

Dunets, A., Latysheva, O., Bitter, N., Vakhrushev, I., Shichiyakh, R. \& Zhuruli, G. 2019. The economic and infrastructural basis for the development of tourist space: The essence, structure and typology. Journal of Environmental Management and Tourism, 10(2), 319-327. doi:10.14505/jemt.v10.2(34).05

Goryushkina, N.E., Vakhrushev, I.B., Akhmetova, M.K., Otto, O.V., Pesotskaya, E.V. \& Voinova, N.E. 2018. The world hotel market: Current state and development trends. International Journal of Mechanical Engineering and Technology, 9(12), 618-627.

Gurman, M.A., Aleksandrova, T.N. \& Shcherbak, L.I. 2017. Flotation of low-grade goldand carbon-bearing ore. Gornyi Zhurnal, (2), 70-74. doi:10.17580/gzh.2017.02.13.

Korableva, O.N., Kalimullina, O.V., Zaytseva, A.A. \& Larionov, A.I. 2018. Elaboration of database for the subject domain of innovation and economic growth potential. Paper presented at the Proceedings of the 31st International Business Information Management Association Conference, IBIMA 2018: Innovation Management and Education Excellence through Vision 2020, 6065-6073.

Korableva, O.N., Kalimullina, O.V., Mityakova, V.N. 2019. Designing a System for Integration of Macroeconomic and Statistical Data Based on Ontology. Advances in Intelligent Systems and Computing, 998, 157-165.

Korauš, A., Gombár, M., Kelemen, P., Polák, J. 2019. Analysis of respondents' opinions and attitudes toward the security of payment systems, Entrepreneurship and Sustainability Issues, 6(4), 1987-2002. http://doi.org/10.9770/jesi.2019.6.4(31)

Kozlova, A.V., Sagayeva, E.Z., Trofimova, L.B. 2017. Audit sample: the concept, methods of its implementation and risks collection: Internal control and audit in the system of effective management of the organization. Publishing house Auditor Moscow, 120125 (In Russian).

Kuznetsova, D.V., Kozlova, M.E., Trofimova, L.B. 2017. Issues of Russian audit. Innovations: prospects, problems, achievements. Materials of the Fifth International Scientific and Practical Conference. Moscow. Publisher: West-Ost-Publishing house Berlin S., May 17, 409-417 (In Russian).

Labanauskis, R., Kasparavičiūtè, A., Davidavičienè, V., Deltuvienė, D. 2018. Towards Quality Assurance of the Study Process Using the Multi-Criteria Decision-Making Method. Entrepreneurship and Sustainability Issues, 6(2), 799-819. http://doi.org/10.9770/jesi.2018.6.2(22)

Leonteva, L.S., Maximov, D.A., Kurbanov, S.A., Afanasyev, I.V., Melnikova, T.E. \& Rezakov, R.G. 2018. Information services and development of effective urban management. International Journal of Civil Engineering and Technology, 9(11), 2518-2525.

Lozhkina, S.L. 2018. Problems of valuation of assets and liabilities at fair value in the conditions of markets of varying degrees of activity Economic and Human Sciences. Publisher: Orlovsky State University. I.S. Turgeneva (Orel) 1(312), 11-20 (In Russian).

Lu, H.Y., Wang, S. 2018. Does lifting the objective-price constraint in revenue recognition increase the value relevance of earnings and revenue? Asian Review of Accounting. Volume 26, Issue 4, 545-570. 
Maguth, B.M. \& Koskey, K.L.K. 2019. Preparing urban youth to live-up to their civic promise? evaluating youth positionality of civic engagement using an arts-based instrument. Journal of Social Studies Education Research, 10(1), 1-37.

Mita, A.F., Siregar, S.V. 2019. The use of the fair value accounting method for investment property in Indonesia Pertanika. Journal of Social Sciences and Humanities, Volume 27, Issue 1, 195-212.

Nikolaeva, N.V., Aleksandrova, T.N. \& Elbendari, A.M. 2018. Ore strength property evaluation in the design of ore preparation cycles. Paper presented at the Geomechanics and Geodynamics of Rock Masses, 1, 333-338.

Pannese, D. and Del Favero, A. 2010. Fair Value Accounting: Affect on the Auditing Profession. Journal of Applied Business Research, 26(3), 43-50.

Prishchepa, L.V. 2017. Fair value in the market valuation system of accounting objects advances in modern science. Publisher: Klyuev Sergey Vasilyevich. Volume 7, 7881 (In Russian).

Ponomareva, N., Zvereva, A., Golubtsova, E., Novikova, E. \& Maximov, D. 2019. Approaches to the improvement of tax auditing for operations with intellectual property in the russian federation. Espacios, 40(10).

Pujiyono, Setiawan, F.A. \& Hutabarat, D.M.T. 2019. A new approach to preventing corruption in Indonesia: A study of the TP4 in Central Java, Indonesia. Journal of Social Studies Education Research, 10(1), 93-115.

Puryaev, A.S. 2015. The mathematical apparatus of compromise of efficiency estimation of investment projects. International Business Management, 9(5), 856-861. https://doi.org/10.3923/ibm.2015.856.861

Talovina, I.V., Lieberwirth, H., Alexandrova, T.N. \& Heide, G. 2017. Supergene oxidesilicate nickel deposits: Mineral-geochemical composition and peculiarities of processing. Eurasian Mining, (1), 21-24. doi:10.17580/em.2017.01.06.

Trofimova, L.B. 2012. The impact of institutional relationships on the formation of fair value as the basic paradigm of the conceptual framework of financial reporting. Scientific and Practical and Theoretical Journal International accounting. Publishing house Finance and Credit, 224, 11-27 (In Russian).

Trofimova, L.B. 2015. Relevant financial statements in the context of the development of integration processes Monograph M., Infra-M., $253 \mathrm{p}$. www.dx.doi.org/10.12737/14656 (In Russian).

Romasheva, N.V., Kruk, M.N. \& Cherepovitsyn, A.E. 2018. Propagation perspectives of $\mathrm{CO} 2$ sequestration in the world. International Journal of Mechanical Engineering and Technology, 9(11), 1877-1885.

Shidov, A.R. 2018. Analysis of discrepancies in the fair value estimation in accordance with IFRS and RSBU. Theory and practice of modern science. Publisher: Institute of Management and Socio-Economic Development (Saratov), 8(38), 5-7 (In Russian).

Smirnova, N.V. \& Rudenko, G.V. 2016. Priorities for improving taxation in oil industry in russia. Indian Journal of Science and Technology, 9(19). doi:10.17485/ijst/2016/v9i19/93907.

Smirnova, N.V. \& Rudenko, G.V. 2017. Tendencies, problems and prospects of innovative technologies implementation by russian oil companies. Journal of Industrial Pollution Control, 33(1), 937-943.

Smirnova, N.N. \& Izotov, E.A. 2017. Methodology for estimating heat losses due to heat effects on a heterogeneous oil reservoir. Journal of Industrial Pollution Control, 33(1), 950-958. 
Singareddy, R.R.R., Ranjan, P., Balamurugan, A. \& Shabana, C. 2019. Financial inclusion remodeling: Including the excluded masses. Space and Culture, India, 6(5), 178188. doi:10.20896/SACI.V6I5.375.

Weinstein, D.E. 2013. New IFRS for consolidating and measuring fair value. From English / D.E. Weinstein et al. LLC Alpina Publishers, 405.

Yücel, C., Acun, I., Tarman, B. \& Mete, T. 2010. A model to explore turkish teachers' ICT integration stages. Turkish Online Journal of Educational Technology, 9(4), 1-9.

Yemelyanov, V.A., Fatkulin, A.R., Nedelkin, A.A., Titov, V.A. \& Degtyarev, A.V. 2019. Software for weight estimation of the transported liquid iron. Paper presented at the Proceedings of the 2019 IEEE Conference of Russian Young Researchers in Electrical and Electronic Engineering. ElConRus, 381-384. doi:10.1109/EIConRus.2019.8657011.

Yemelyanov, V., Tochilkina, T., Nedelkin, A. \& Shved, E. 2018. Automation of monitoring and diagnosing the technical condition of torpedo ladle cars. Paper presented at the MATEC Web of Conferences, 239, doi:10.1051/matecconf/201823904003. 